\title{
Potential cues for conspecific calling signal recognition in leafhoppers of the genus Doratura J. Sahlb. (Homoptera: Auchenorrhyncha: Cicadellidae: Deltocephalinae)
}

\author{
Признаки, потенщиально служащие для распознавания \\ конспецифических призывных сигналов у цикадок \\ pода Doratura J. Sahlb. (Homoptera: Auchenorrhyncha: \\ Cicadellidae: Deltocephalinae)
}

\section{D.Yu. Tishechkin \\ A.Ю. Тишечкин}

Department of Entomology, Faculty of Biology, M.V. Lomonosov Moscow State University, Vorobyevy Gory, Moscow 119991, Russia. Email: macropsis@yandex.ru

Кафедра энтомологии Биологического факультета Московского государственного университета имени М.В. Ломоносова, Воробьевы Горы, Москва 119991, Россия.

KEY WORDS: leafhoppers, vibrational communication, calling signals, signal recognition, Cicadellidae, Deltocephalinae, Doratura.

КЛЮЧЕВЫЕ СЛОВА: цикадовые, вибрационная коммуникация, призывные сигналы, распознавание сигналов, Cicadellidae, Deltocephalinae, Doratura.

ABSTRACT. Comparative analysis of calling signals in seven species of Doratura J. Sahlb. showed that the signals of different species have the same general scheme of temporal pattern and differ from each other mainly in quantitative parameters, namely, in durations of short and long syllables, and in one case, also in pulse repetition period. Apparently, these traits are main cues for conspecific signal recognition in this genus.

РЕЗЮМЕ. Сравнительный анализ призывных сигналов семи видов рода Doratura J. Sahlb. показал, что сигналы разных видов имеют одинаковый общий план временно́го рисунка и различаются преимущественно количественными параметрами, а именно, продолжительностью короткой и длинной серий, а в одном случае - также периодом повторения пульсов. Очевидно, именно эти признаки служат для распознавания конспецифических сигналов у представителей данного рода.

\section{Introduction}

Many insect species use air-borne or substrate-transmitted (i.e. vibrational) acoustic signals (songs) for recognition and locating conspecific individuals. Determination of the features of male calling song that are important in conspecific mate recognition usually is performed by examining the response of receptive female to intact and/or modified male signals. For small Auchenorrhyncha this method as a rule is the only possible one, since the representatives of this group usually produce most elaborate calling songs; the works by Inoue [1982] and Hunt et al. [1992] can be mentioned as examples.

In certain other taxa, e.g. in gomphocerine grasshoppers (Orthoptera: Acrididae: Gomphocerinae) alternative, "indirect" method of revealing parameters playing a crucial role in signal recognition can be used. It is based on comparative investigation of calling songs of sympatric species. It is evident, that in the communities of animals producing acoustic signals successful communication is possible only if the signal of each species differs from the ones of every other community member in at least one physical parameter. Consequently, these parameters are potential cues for conspecific song recognition.

For instance, in experiments with retranslation of model signals to females of gomphocerine grasshoppers (Orthoptera: Acrididae: Gomphocerinae) it was demonstrated that syllable repetition period and syllable pattern including the presence or absence of gaps in syllable are main characters for conspecific signal recognition [e.g. Vedenina \& Zhantiev, 1990; Eiríksson, 1993]. Later, comparative investigation of acoustic signals in grasshopper communities yielded the same results: it was shown that communication channel segregation is achieved through the differences in the same basic features, the general scheme of signal structure, syllable repetition period and syllable pattern [Tishechkin \& Bukhvalova, 2010].

As noted above, in many taxa of small Auchenorrhyncha calling signal pattern is very complicated and diverse. For this reason comparative analysis of signals of sympatric species usually is useless, since the song patterns in different species quite often have nothing in common with each other. However, examples of simi- 
larity of signal patterns in different species are known as well [e.g. Tishechkin, 2008, 2010]. The genus Doratura J. Sahlberg, 1871 (Homoptera: Auchenorrhyncha: Cicadellidae: Deltocephalinae: Doraturini) provides one more example of this kind. Calling signals of the representatives of the genus are rather uniform and typically consist of two syllables differing from each other only in duration. The aim of this study is to reveal potential cues for conspecific signal recognition in the structure of male calling songs in this genus.

All Doratura species are grass-dwelling insects most diverse and abundant in steppe zone. They feed on various Graminea or, occasionally, on certain species of Allium (Alliaceae). Recently it was demonstrated that in mixed grass thickets vibrational signals of small Auchenorrhyncha can be transmitted from plant to plant both via the leaves or stems touching each other and via the roots [Tishechkin, 2011b]. As a result, in grass-dwelling leafhoppers differences in host specialisation by no means provide acoustic isolation. Based upon the above reasoning we believe that different species of Doratura having overlapping ranges can be safely considered to be sympatric and apparently can perceive the signals of each other.

\section{Material and methods}

Vibrational signals were registered by means of piezo-electric crystal gramophone cartridge connected to the microphone input of cassette recorder "Elektronika-302-1" via the custom-made matching amplifier. Recordings were made under laboratory conditions immediately after collecting the insects.

Data on insect collecting sites are given in the Table 1. The specimens investigated are deposited in the collection of the Zoological Museum of M.V. Lomonosov Moscow State University.

\section{Results}

Calling signals of Doratura consist of single or repeated phrases. Each phrase includes two syllables separated by gap, long (first) syllable followed by short (second) one (Fig. 1). The only exception is D. impudica
Horvath, 1897 having not one, but 7-15 short syllables in each phrase (Figs 2-4). Both long and short syllables consist of uniform pulses. In all species studied this basic structure occasionally can vary to more or less extent due to the presence of additional elements in certain phrases. Usually, these are successions of pulses or syllables preceding the main part of a phrase (Figs 5-8).

Two groups of potentially sympatric species can be recognized in our material. Doratura exilis Horvath, 1903, D. stylata (Boheman, 1847), D. homophyla (Flor, 1861), D. impudica Horv., and D. salina Horvath, 1903 are widespread in the steppe zone of European Russia and sometimes can be found in the same locality in various combinations. D. stylata, D. homophyla, D. gravis Emeljanov, 1966, and D. lukjanovitshi Kusnezov, 1929 were found in the steppes of South Siberia including southern Tyva (Erzin village), where our investigations were conducted; it should be added that these four species were also recorded from this locality by Vilbaste [1980].

Oscillograms of calling signals of seven species are given on Figs 9-22, comparison of signal temporal parameters is provided in the Table 2.

As can be seen from the data presented, among five Doratura species inhabiting the steppes of European Russia there are two pairs of species producing calling signals with similar temporal parameters.

The first two ones are D. stylata and D. salina (Figs 9, 16 and 10,17). Duration ranges of both long and short syllables in these species overlap almost completely. Gap durations have very close values, even if formally different in most cases. However, D. salina differs both from $D$. stylata and from all other species by strikingly long pulse repetition period in the long syllable; in addition it is not constant as in other species, but decreases towards the end of syllable (Fig. 23).

The second pair of species are D. homophyla and D. impudica (Figs 11, 18 and 12, 19). Their calling signals are similar with these of the former two species in duration of a long syllable, but short syllables in both ones are almost half as long as in D. stylata and D. salina (Table 2). Syllable durations in the songs of D. homophy$l a$ and $D$. impudica have close or even overlapping values, but the song of D. impudica differ clearly from the

Table 1. Data for signal recordings used in the paper.

Таблица 1. Данные об использованных в статье записях сигналов.

\begin{tabular}{|l|l|}
\hline \multicolumn{1}{|c|}{ Species } & \multicolumn{1}{c|}{ Locality } \\
\hline Doratura exilis Horv. & $\begin{array}{l}\text { North Caucasus, North Ossetia: } \\
\text { 1. Mountain steppes in Sadono-Unal Depression ca. 20 km south of Alagir. } \\
\text { 2. Steppes on Sunzhenskiy Mtn. Ridge near El'khotovo village. }\end{array}$ \\
\hline D. stylata (Boh.) & Moscow Area, Mytishchi District, env. Pirogovo Town. \\
\hline D. homophyla (F1.) & $\begin{array}{l}\text { 1. Moscow Area, Voskresensk District, env. Beloozerskiy Town. } \\
\text { 2. Ukraine, Kherson Area, Sivash. }\end{array}$ \\
\hline D. impudica Horv. & Moscow Area, Serpukhov District, env. Luzhki Vill. \\
\hline D. salina Horv. & Saratov Area, Krasnokutskiy District, env. Dyakovka Vill. \\
\hline D. gravis Em. & South Siberia, southern Tyva, env. Erzin. \\
\hline D. lukjanovitshi Kusn. & South Siberia, southern Tyva, env. Erzin. \\
\hline
\end{tabular}


signals of other species due to additional character, namely, high number of short syllables in the end of a phrase.

Calling signals of the fifth species, $D$. exilis differ from the songs of the previous four ones due to very long first syllable (Figs 13, 20).

Among four species found in the steppes of southern Tyva D. stylata and D. homophyla are similar in duration of long syllables, but the short syllable in the former species is about twice as long as in the latter one (Figs 9, 16 and 12,19$)$. Also, the gap in the phrases of $D$. homophyla is 2-8 times as long as in D. stylata. D. gravis has the same gap duration as in D. stylata and the same duration of the short syllable as in D. homophyla, but differs distinctly from both species by much more prolonged first (long) syllable (Figs 14, 21). Finally, D. lukjanovitshi produce signals with exceptionally long first syllable lasting approximately from 3.5 up to $6 \mathrm{~s}$ (Figs 15, 22).

\section{Discussion}

In small Auchenorrhyncha, even the signals of closely related species quite often differ considerably in qualitative characters. Important role of these differences were demonstrated in playback experiments [Inoue, 1982; Hunt et al., 1992].

Comparative analysis of signal structure in the groups of cryptic species also provides indirect evidence that

$\begin{array}{llllll}\mathbf{p} & \mathbf{h} & \mathbf{r} & \mathbf{a} & \mathbf{s} & \mathbf{e}\end{array}$

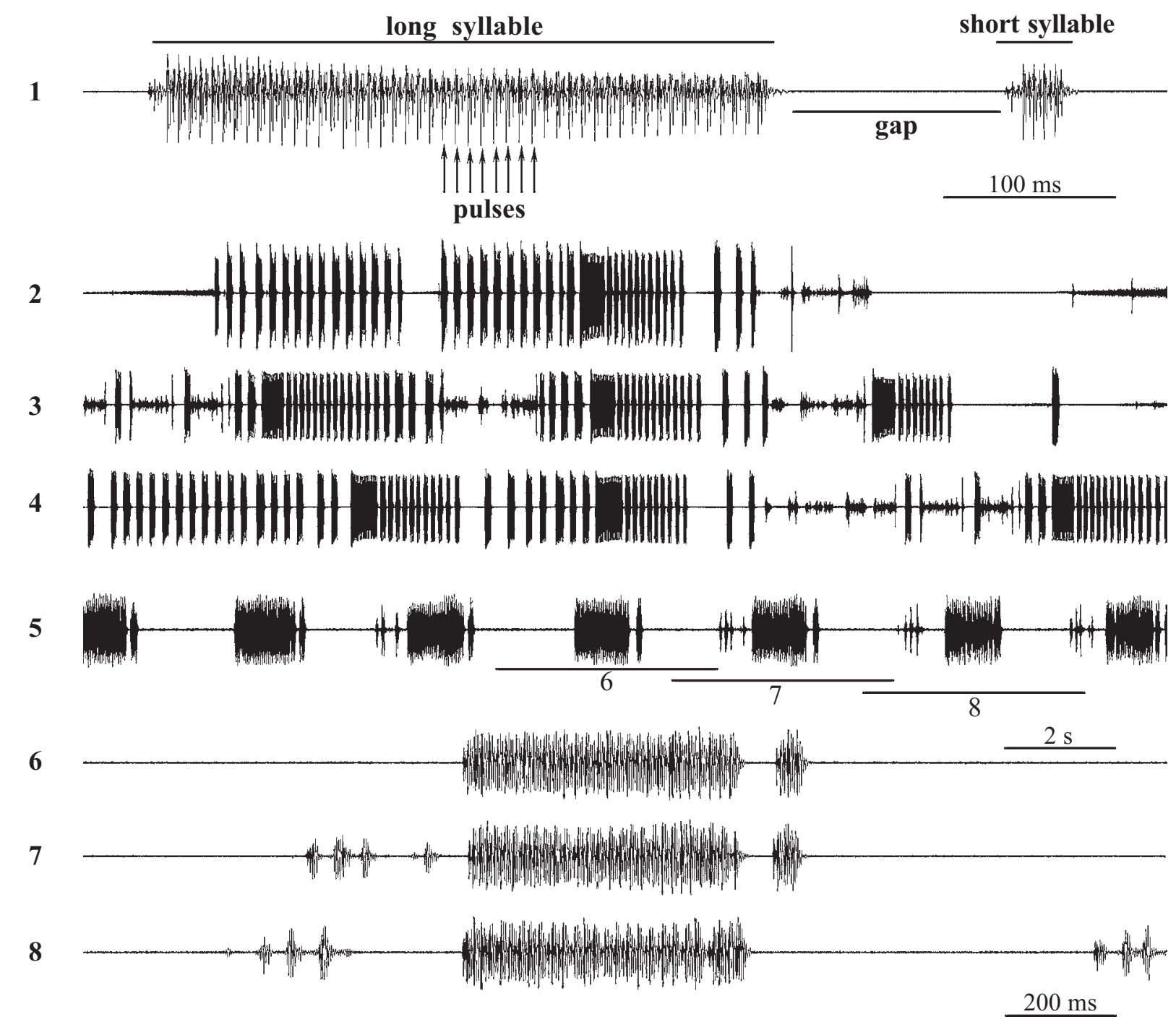

Figs. 1-8. Oscillograms of calling signals of the representatives of the genus Doratura. 1 - phrase of a signal of D. homophyla illustrating terminology used in the paper; 2-4 - variability of a phrase temporal pattern in D. impudica; 5-8 - same, D. homophyla. Faster oscillograms of the parts of signal indicated as " $6-8$ " are given under the same numbers.

Рис. 1-8. Осциллограммы призывных сигналов представителей рода Doratura. 1 - фраза сигнала D. homophyla, иллюстрирующая используемую в статье терминологию; 2-4 - изменчивость временно́го рисунка фразы D. impudica; 5-8 - то же, D. homophyla. Фрагменты сигнала, помеченные цифрами “6-8”, представлены при большей скорости развёртки на осциллограммах под соответствующими номерами. 


\section{9}
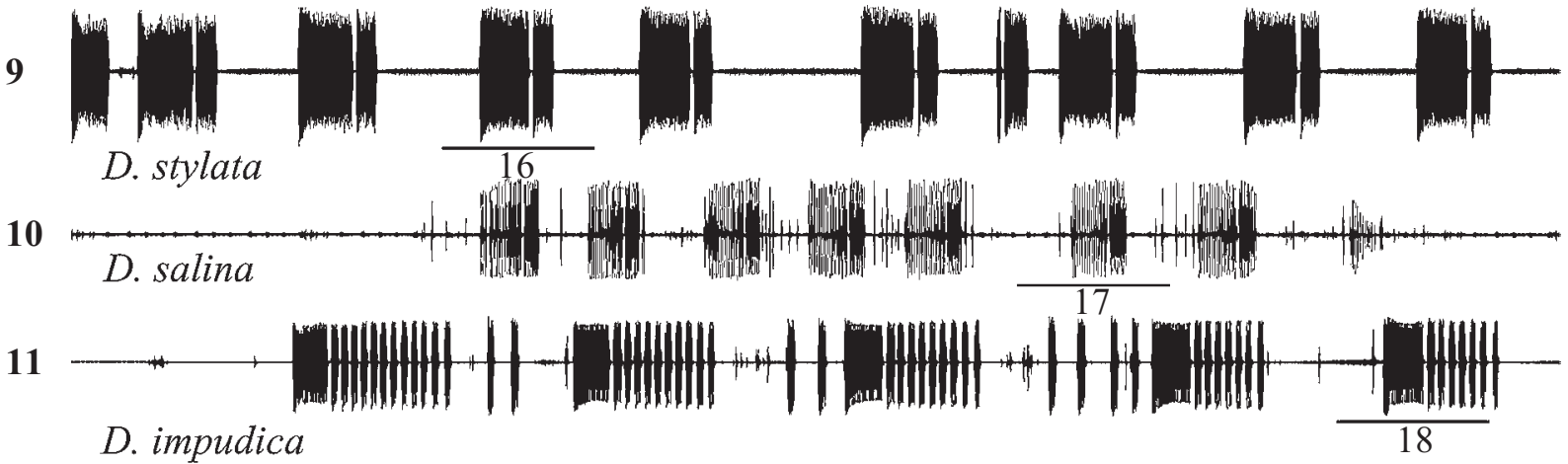

12

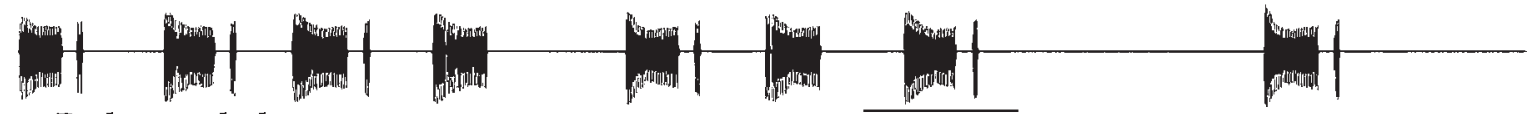

D. homophyla

13

D. exilis

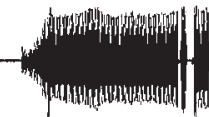

19

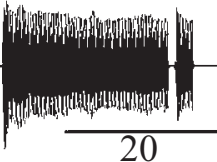

14

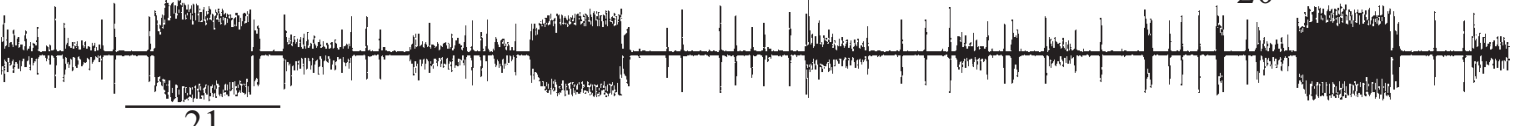

D. gravis

15

D. lukjanovitshi

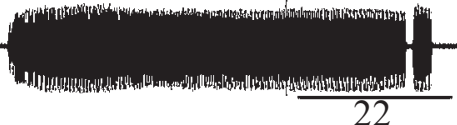

$2 \mathrm{~s}$

16

D. stylata

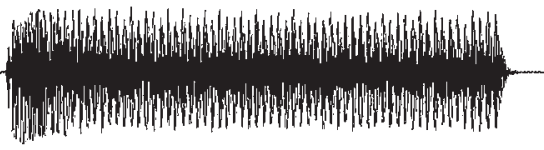

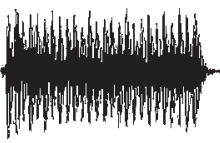

17

D. salina

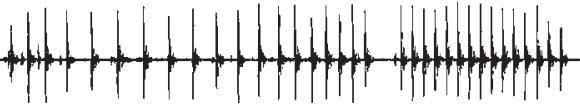

18

D. impudica

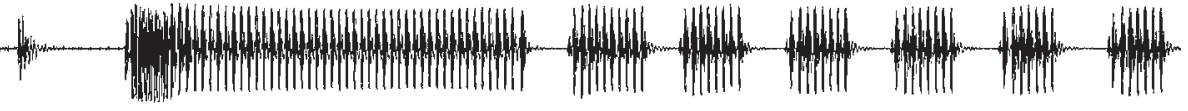

19

D. homophyla

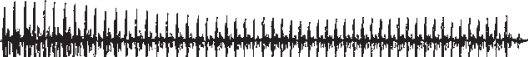

(n)

Hillit.

20

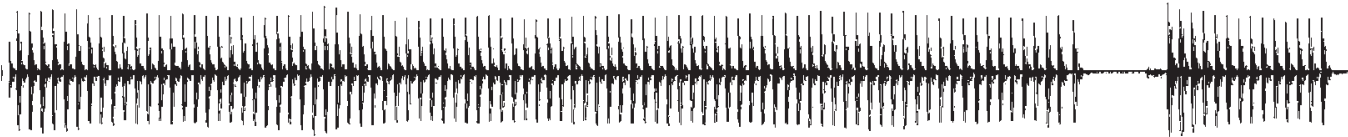

D. exilis

21

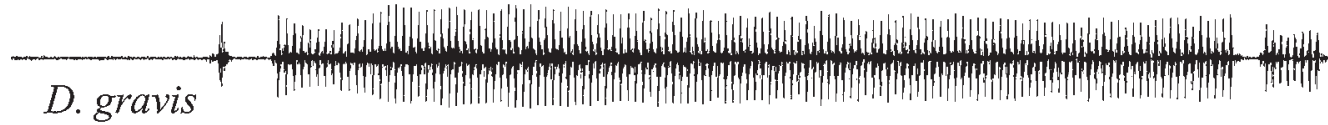

22

Ly)

D. lukjanovitshi

$200 \mathrm{~ms}$

Figs. 9-22. Oscillograms of calling signals of the species of the genus Doratura. Faster oscillograms of the parts of signals indicated as "16-22" are given under the same numbers.

Рис. 9-22. Осциллограммы призывных сигналов видов рода Doratura. Фрагменты сигналов, помеченные цифрами “16-22”, представлены при большей скорости развёртки на осциллограммах под соответствующими номерами. 
Table 2. Temporal parameters of calling signals of Doratura species. Таблица 2. Временные параметры призывных сигналов видов Doratura.

\begin{tabular}{|c|c|c|c|c|c|c|}
\hline Species & \begin{tabular}{|c} 
Air \\
temperature \\
during \\
recording, ${ }^{\circ} \mathrm{C}$
\end{tabular} & $\begin{array}{c}\text { Long syllable } \\
\text { duration, ms }\end{array}$ & $\begin{array}{l}\text { Short syllable } \\
\text { duration, ms }\end{array}$ & $\begin{array}{c}\text { Gap } \\
\text { duration, } \\
\text { ms }\end{array}$ & $\begin{array}{l}\text { Pulse } \\
\text { repetition } \\
\text { period, ms }\end{array}$ & Additional characters \\
\hline D. salina & $26-28$ & $455-658$ & $189-238$ & $19-39$ & $\begin{array}{c}15-51 \text { (long } \\
\text { syllable) } \\
13-16 \text { (short } \\
\text { syllable) }\end{array}$ & $\begin{array}{l}\text { Pulse repetition } \\
\text { period in long } \\
\text { syllable decreases } \\
\text { towards its end }\end{array}$ \\
\hline \multirow{2}{*}{ D. stylata } & 26 & $452-769$ & $205-288$ & $34-86$ & $9-11$ & \multirow{2}{*}{ None } \\
\hline & 23 & $514-808$ & $327-363$ & $35-70$ & $10-11$ & \\
\hline D. impudica & 27 & $407-556$ & $83-114$ & $22-44$ & $9-11$ & Many short syllables \\
\hline \multirow{2}{*}{ D. homophyla } & $26-27$ & $606-781$ & $78-103$ & $180-275$ & $13-15$ & \multirow{2}{*}{ None } \\
\hline & 21 & $636-686$ & $91-120$ & $192-287$ & $17-19$ & \\
\hline D. exilis & 24 & $1240-2150$ & $184-234$ & $58-123$ & $15-16$ & None \\
\hline D. gravis & 22 & $920-1490$ & $74-86$ & $19-37$ & $9-10$ & None \\
\hline D. lukjanovitshi & 22 & $3530-6160$ & $234-262$ & $68-90$ & $10-11$ & None \\
\hline
\end{tabular}

differences in the general scheme of temporal pattern play the main role in conspecific signal recognition. In most cases different species similar in morphological characters demonstrate distinct qualitative differences in calling song patterns. This is the case with Neoaliturus fenestratus (Herrich-Schäffer, 1834) species group [Tishechkin, 2007], Laburrus gr. impictifrons (Boheman, 1852) [Tishechkin, 2009] and many other species of Cicadellidae.
If the signals of different species have the same general scheme of temporal pattern, repetition period of signal elements (i.e. pulses or syllables) has prime importance for signal recognition. It was demonstrated, that differences in pulse repetition period between rice- and weed-associated populations of Nilaparvata lugens (Stål, 1854) (Delphacidae) result in reproductive isolation between these forms, which actually belong to different

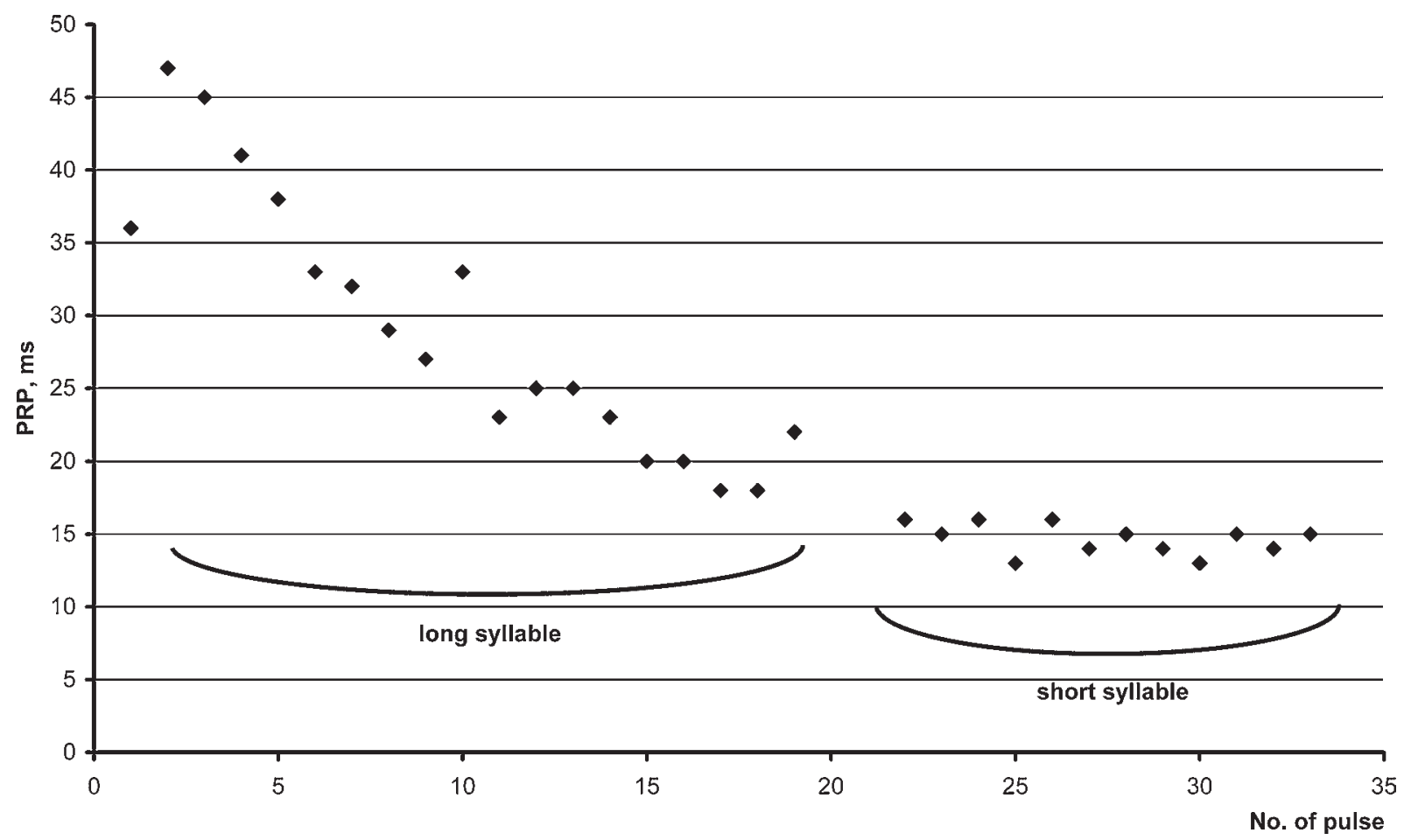

Fig. 23. The change of pulse repetition period (PRP) from the beginning to the end of syllables in a phrase of Doratura salina. For each point the number of pulse from the beginning of a phrase is laid off as abscissa, the PRP measured from the beginning of this pulse to the beginning of the next one is laid off as ordinate.

Рис. 23. Изменение периода повторения пульсов (ППП) от начала к концу серий во фразе Doratura salina. По горизонтальной оси для каждой точки отложен порядковый номер пульса от начала фразы, по вертикальной - ППП, измеренный от начала этого пульса до начала следующего. 
biological species [Claridge et al., 1985a]. Similar results were obtained for populations of $N$. lugens from Southeast Asia and Northern Australia [Claridge et al., 1985b].

Duration and repetition period of signal components are affected by temperature variations. The effects on signal parameters of Javesella pellucida (Fabricius, 1794) are of an order of magnitude that ranges from about 1.7 to 2.1 per $10^{\circ} \mathrm{C}$ [de Vrijer, 1984]. In playback experiments percentage of females responding to male calling song dropped considerably, when the temperature differences between male and female exceeded $5^{\circ} \mathrm{C}$. At the temperature difference of $10^{\circ} \mathrm{C}$ conspecific signal recognition was almost impossible. Consequently, it is reasonable to assume that differences of an order of magnitude about 2 in any parameter between the signals of two species are sufficient to provide their reproductive isolation.

The results of comparative investigations of signals of sympatric species of Aphrophora Germar, 1821 (Homoptera: Aphrophoridae) are in good agreement with these data [Tishechkin, 2011a]. Calling songs of different species for the most part differ from each other in qualitative characters (single or regularly repeated phrases, syllables with or without gaps, etc.). Two species producing signals with the same general scheme of temporal pattern (single phrases consisting of syllables with gaps) differ widely from each other in syllable repetition period, in the first species this parameter being about half as great as in the second one.

Similar situation is observed in the species of $D o$ ratura. In two of seven species investigated signals have unique traits: unusually long pulse repetition period in D. salina (Fig. 17) and not one, but several short syllables per phrase in D. impudica (Fig. 18). Signals of all other species differ from each other only in quantitative characters, mainly in duration of syllables. If the long syllables in two species have close durations, short ones will differ widely (e.g. D. stylata and D. homophyla, Figs 16 and 19) and vice versa (e.g. D. stylata and D. lukjanovitshi, Figs 9, 16 and 15, 22).

It is particularly remarkable that the differences between heterospecific signals in all cases have the same order of magnitude as between the signals of $J$. pellucida at the temperature difference of $10{ }^{\circ} \mathrm{C}$, when conspecific signal recognition becomes almost impossible. If any parameter has partially overlapping or even non-overlapping, but close values in different species, this is, apparently, insufficient for their acoustic segregation. In such cases the differences are "strengthened" by additional more reliable characters. For instance, in certain cases species formally differ in pulse repetition period (e.g. $D$. homophyla and D. impudica, Table 2), but this character evidently plays decisive role only in distinguishing between D. stylata and D. salina, since the latter species differs distinctly in this character from all other ones.

From the above, it might be assumed that in the representatives of Doratura the main traits for conspecific signal recognition are durations of long and short syllables in a phrase. Pulse repetition period can play a key role in this process only if the signals differ widely from each other in this parameter. Gap duration as itself apparently plays no role in signal recognition, since it has close or overlapping values in most cases. Also, in all cases when two species has distinctly different gap duration (e.g. D. exilis and D. stylata, D. homophyla and D. impudica) their signals necessarily differ from each other also in additional traits (duration of long syllable in the first pair of species and the number of short syllables in the second pair).

ACKNOWLEDGEMENTS. The study was supported by Russian Foundation for Basic Research (No. 10-04-00275-a).

\section{References}

Claridge M.F., Den Hollander J. \& Morgan J.C. 1985a. The status of weed-associated populations of the brown planthopper, Nilaparvata lugens (Stål) — host race or biological species? // Zool. J. Linn. Soc. Vol.84. P.77-90.

Claridge M.F., Den Hollander J. \& Morgan J.C. 1985b. Variation in courtship signals and hybridisation between geographically definable populations of the rice brown planthopper, Nilaparvata lugens (Stål) // Biol. J. Linn. Soc. Vol.24. P.35-49.

de Vrijer P.W.F. 1984. Variability in calling signals of the planthopper Javesella pellucida (F.) (Homoptera: Delphacidae) in relation to temperature, and consequences for species recognition during distant communication//Netherlands J. Zool. Vol.34. No.3. P.388-406.

Eiríksson T. 1993. Female preference for specific pulse duration of male songs in the grasshopper, Omocestus viridulus // Animal Behav. Vol.45. No.3. P.471-477.

Hunt R.E., Fox J.P. \& Haynes K.F. 1992. Behavioral response of Graminella nigrifrons (Homoptera: Cicadellidae) to experimentally manipulated vibrational signals // J. Insect Behav. Vol.5. No.1. P.1-13.

Inoue H. 1982. Species-specific calling sounds as a reproductive isolating mechanism in Nephotettix spp. (Hemiptera: Cicadellidae) // Appl. Entomol. Zool. Vol.17. No.2. P.253-262.

Tishechkin D.Yu. 2007. Review of Neoaliturus gr. fenestratus (Herrich-Schäffer, 1834) (Homoptera: Cicadellidae) of the fauna of Russia // Russian Entomol. J. Vol.16. No.4. P.415-424.

Tishechkin D.Yu. 2008. On the similarity of temporal pattern of vibrational calling signals in different species of Fulgoroidea (Homoptera: Auchenorrhyncha) // Russian Entomol. J. Vol.17. No.4. P.343-351.

Tishechkin D.Yu. 2009. On the taxonomic status of Laburrus confusus Vilbaste, 1980 (Homoptera: Cicadellidae: Deltocephalinae) // Russian Entomol. J. Vol.18. No.2. P.81-86.

Tishechkin D.Yu. 2010. Vibrational signals in sympatric species of leafhoppers: Paralimnini (Homoptera: Cicadellidae: Deltocephalinae) in the valley of Irkut River, Eastern Siberia - a case study // Russian Entomol. J. Vol.18 (for 2009). No.4. P.265272.

Tishechkin D.Yu. 2011a. Calling signals in sympatric species of the far-eastern Aphrophora (Homoptera: Auchenorrhyncha: Aphrophoridae): regularities of communication channel segregation // Russian Entomol. J. Vol.20. No.1. P.57-64.

Tishechkin D.Yu. 2011b. Do different species of grass-dwelling small Auchenorrhyncha (Homoptera) have private vibrational communication channels? // Russian Entomol. J. Vol.20. No.2. P.135-139.

Tishechkin D.Yu. \& Bukhvalova M.A. 2010. Acoustic communication in grasshopper communities (Orthoptera: Acrididae: Gomphocerinae): segregation of acoustic niches // Russian Entomol. J. Vol.18 (for 2009). No.3. P.165-188.

Vedenina V.Yu. \& Zhantiev R.D. 1990. [Recognition of acoustic signals in sympatric species of locusts] // Zoologicheskiy Zhurnal. Vol.69. No.2. P.36-45 [in Russian, with English summary].

Vilbaste Yu.G. 1980. [Fauna of Cicadinea of Tuva]. Tallinn: Valgus Publ. 219 pp. [in Russian, with English summary]. 